\title{
HUMAN BERTIELLOSIS IN GOIÁS, BRAZIL: A CASE REPORT ON HUMAN INFECTION BY Bertiella sp. (CESTODA: ANOPLOCEPHALIDAE)
}

\author{
Julieta M. PAÇÔ, Dulcinéia M.B. CAMPOS \& José Luiz de Barros ARAÚJO
}

\begin{abstract}
SUMMARY
The authors report on a new case of human Bertiellosis in a 2-year old female patient who was born in Goiânia-Goiás (Brazil) and has had history of permanent dwelling in an area frequently visited by simians in Mato Grosso (Brazil). At the time of diagnosis the patient showed inappetence, abdominal pain, and loss of weight. Eggs and proglottids were found in her stool and were identified as Bertiella sp. The objective of this report is to register the third case of human Bertiellosis in Brazil, characterizing one more case of helminthic zoonosis.
\end{abstract}

KEYWORDS: Anoplocephalidae; Bertiella; Human Bertiellosis; Zoonosis.

\section{INTRODUCTION}

The Anoplocephalidae family includes heterotoxenic cestodes that use mites as intermediate hosts. In their adult phase, these cestodes are parasites of reptiles, birds, and mammals. The subfamily Anoplocephalinae comprises all Anoplocephalidae transmitted by oribatid mites, including the genus Bertiella ${ }^{2,9,16,17,19,21}$.

Cestodes of the genus Bertiella have been reported as parasites in marsupials, rodents, dermopterans, and primates in Asia, Africa, Australia, Oceania, and the Americas $2,5,12,15,16,17,21$. The species B. studeri and B. mucronata in the genus Bertiella can infect humans. Human Bertiellosis caused by $B$. studeri was first detected by BLANCHARD $(1913)^{6}$ in a 8-year old female patient from Mauritius Island. On the other hand, CRAM $(1928)^{10}$ registered the first case of B. mucronata infection in a young patient from Cuba. Both species are very similar and they require a specialist to discriminate between them ${ }^{24}$. Since the initial records, several cases of human Bertiellosis have been reported in the literature, with findings in Latin America, including case reports of B. mucronata infection in Cuba, Brazil, Argentina, and Paraguay ${ }^{1,9,10,11,16,18,20,21}$ and B. studeri infection in the United States ${ }^{27}$. Moreover, CRAM (1928) $)^{10}$ and CAMERON (1929) ${ }^{7}$ considered human Bertiellosis endemic in the West Indies. Both authors declared their lack of knowledge about the mode and time of introduction of Bertiellosis in that region. DENEGRI \& PEREZ-SERRANO (1997) ${ }^{16}$ carried out a comprehensive review of all human cases of Bertiellosis reported in the literature, describing a higher prevalence of human infection caused by $B$. studeri when compared to B. mucronata. The authors also emphasized the increased potential of this helminthic zoonosis ${ }^{16}$.
In order to complete its life cycle, the genus Bertiella requires a definitive host, generally a mammal, as well as an intermediate host, an oribatid mite which is an important component of the soil fauna ${ }^{13,15,16,21,24}$. Accidental ingestion of the intermediate host infected with cysticercoids becomes the way of contamination for the vertebrate host $\mathrm{t}^{14,15,24}$.

In Brazil, the first human case of parasitism by B. mucronata was described by PESSOA (1930) $)^{21}$ in a 29 year-old patient from São Paulo and a second report on human infection was described by COSTA et al. $(1967)^{9}$ in a patient from Formiga (Minas Gerais) $)^{9,11}$. The main objective of this article is to report on a third case of human parasitism by Bertiella sp. (Cestoda - Anoplocephalidae) in Brazil.

\section{CASE REPORT}

The present report refers to a 2-year old female patient born in the city of Goiânia state of Goiás but who has also lived in the State of Mato Grosso, Brazil in a rural area known to be inhabited by simians. The patient's mother reported that "maggots" were being spontaneously eliminated by the child in the intervals between evacuation. The child exhibited abdominal pain, inappetence, vomiting and weight loss. She was not hospitalized and after parasitological diagnosis follow up was not possible because the patient has not returned to the University.

\section{MATERIALS AND METHODS}

Fecal samples were evaluated by the following methods: spontaneous sedimentation, Faust and colleagues, Baermann-Moraes and sieving. Eggs and proglottids were collected from fresh feces from the patient. 
Forty eggs were measured using the micrometrical ocular technique. After sieving, proglottids were fixed by compression in cold $10 \%$ formaldehyde solution and subsequently stained with Blachin carmine.

\section{RESULTS}

Eggs were typical, measuring approximately $40 \mu \mathrm{m}(39 \mu \mathrm{m}-41$ $\mu \mathrm{m})$ of diameter, containing one rugged embryonic membrane and a bifurcated pyriform apparatus at its center (Fig. 1 and 2). Proglottids were released attached to each other, in variable numbers. The mature proglottids were much broader than long containing numerous testes, genital pores irregularly alternated and vagina surrounded by well developed cylindrical cells.

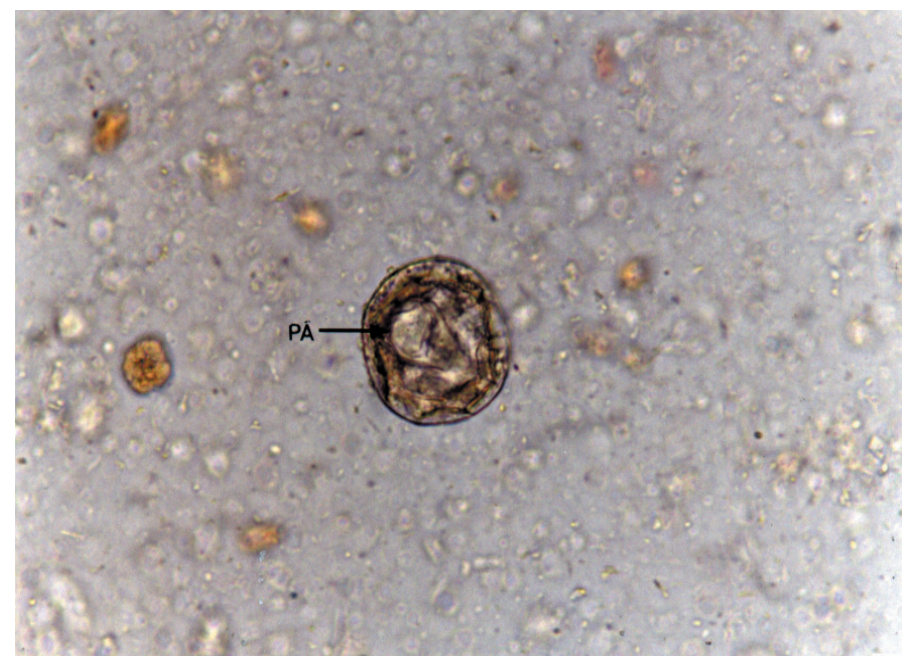

Fig. 1 - Eggs of Bertiella sp. showing a bifurcated pyriform apparatus (PA), 400x.

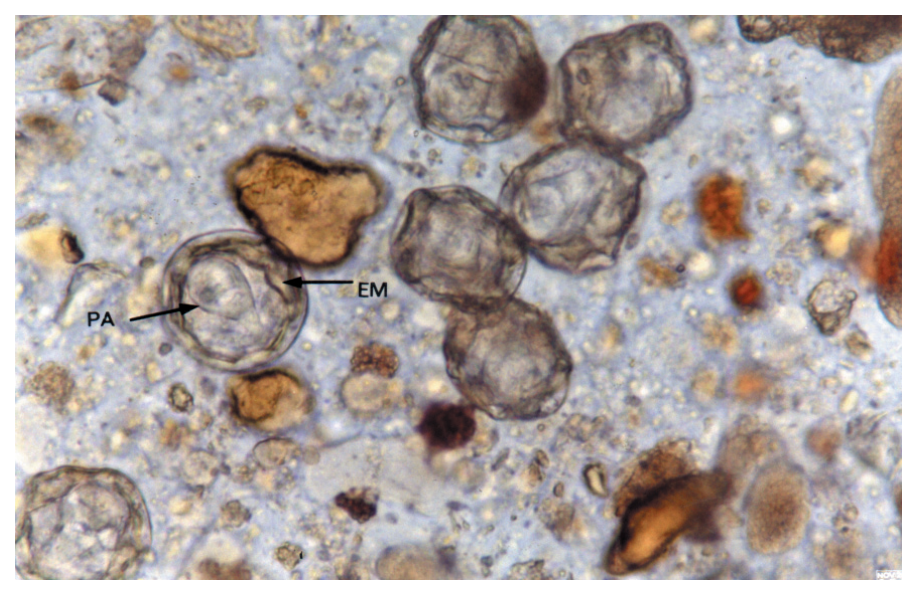

Fig. 2 - Eggs of Bertiella sp. showing one rugged embryonic membrane (EM) and a bifurcated pyriform apparatus (PA), 400x.

\section{DISCUSSION}

The genus Bertiella (Stiless and Hassal, 1902) is characterized by medium-sized forms with well-marked segmentation, a short neck, irregularly alternated genital pores and one set of genitalia per segment. Other characteristics include numerous testes scattered in the proglottid's parenchyma, cirrus pouch well developed, with an internal seminal vesicle. The vagina is surrounded by a layer of glandular cells and gravid uterus presented as a transverse tube filled with eggs with well-developed pyriform apparatus ${ }^{28,29}$. CHANDLER $(1925)^{8}$ recognized six humaninfecting species while CRAM $(1928)^{10}$ considered three species able to infect humans and nineteen, occurring in other mammals ${ }^{28}$. BAER $(1927)^{4}$ classified the genus Bertiella into two species occurring in primates, $B$. studeri in the Eastern Hemisphere and B. mucronata in the Western Hemisphere. The other species, he regarded as synonymous of $B$. studeri whose range of primate hosts included Homo sapiens, Simia satyrus, Anthropithecus troglodytes, Hylobates hoolock, Cercopithecus pygerythhraeus, Cercopithecus schmidti, Cynomolgus sinicus and Cynomolgus fascicularis ${ }^{28,29}$.

The cases of human parasitism by Bertiella are frequently accidental and are generally associated with common dwelling areas for humans and monkeys. Despite the reduced number of reported cases, approximately 56, recent reports have demonstrated an increase in both human and non- human primate infections $\mathbf{s}^{1,3,6,7,9,16,24,27}$.

Bertiella diagnosis is made through the presence of eggs and proglottids in patient's feces. Proglottids can also be spontaneously released and, in these cases, adequate identification requires skilled professionals and is fundamental for the diagnosis ${ }^{12,16,21,24,26}$

Oribatid mites are the intermediate hosts and are natural components of the soil fauna. Therefore, their worldwide geographic distribution makes prophylactic attempts difficult ${ }^{16,21,24}$. POPE (1966) $)^{22}$ and SANTA CRUZ et al. (1995) ${ }^{23}$ emphasized the remarkable increase of $B$. mucronata infected monkeys in Argentina, reaching 420\% higher rates in the last years $^{22,23,25}$. Although this helminthic zoonosis is endemic in countries such as West Indies, low prevalence numbers are found in Brazil. Cebus apella is a common simian species in Central West Brazil but there are no reports of Bertiella species infecting these primates in the state of Goiás.

We report the third case of human bertiellosis in Brazil and the first in the state of Goiás. Drugs used in the treatment for cestoda, such as quinacrine, niclosamide, praziquantel and albendazole have been prescribed to treat the human bertiellosis. The helminth is not well adapted to the human species and intense weight loss is an important clinical sign of the infection ${ }^{21}$. Information about therapy regimen implemented, parasitological cure and current patient clinical status could not be obtained because, after diagnosis, the patient and her parents have not returned to our laboratory at the University.

\section{RESUMO}

\section{Parasitismo humano por Bertiella sp. (Cestoda-Anoplocephalidae) no Estado de Goiás, Brasil}

Relata-se o encontro de um novo caso de bertiellose humana em paciente do sexo feminino, 2 anos, natural de Goiânia, Estado de Goiás com histórico de permanência em área freqüentada por símios no Estado de Mato Grosso. A paciente apresentava inapetência, dores abdominais, emagrecimento e eliminava nas fezes ovos e proglotes que foram 
identificados como Bertiella sp. O objetivo do presente trabalho é registrar o encontro do terceiro caso de parasitismo humano por Bertiella sp. (Cestoda-Anoplocephalidae) no Brasil, caracterizando mais um caso de zoonose helmíntica.

\section{REFERENCES}

1. ADAMS, A.R.D. - A fourth case of human infestation with B. studeri (Cestoda) in Mauritius. Ann. trop. Med. Parasit., 29: 361-362, 1935.

2. AFRICA, C.M. \& GARCIA, E.Y. - The occurrence of Bertiella in man, monkey and dog in the Philippines. Philipp. J. Sci., 56: 1-11, 1935.

3. BACigAlupo, J. - Primer caso humano de Bertiella sp. en Sud América. Rev. Soc. mex. Hist. nat., 10: 177-183, 1949.

4. BAER, J.G. - Monographie des cestodes de la famille des Anoplocephalides. Bull. biol. France et Belg., 10: 241, 1927. Apud: WARDLE, R.A. \& MCLEOD, J.A. - The zoology of tapeworms. London, Minnesota Press, 1952. p. 362-364

5. BANDYOPADHYAY, A.K. \& MANNA, B. - The pathogenic and zoonotic potentiality of Bertiella studeri. Ann. trop. Med. Parasit., 81: 465-466, 1987.

6. BLANCHARD, R. - Bertiella satyri de l'Orang-outang, est aussi parasite de l'homme. Bull. Acad. Méd. (Paris), 9: 286-296, 1913.

7. CAMERON, T.W.M. - A new record of the occurrence of a tapeworm of the genus Bertiella in man. J. Helmint., 7: 231-234, 1929.

8. CHANDLER, A.C. - New records of Bertiella satyri (Cestoda) in man and apes. Parasitology, 17: 421-425, 1925. Apud: WARDLE, R.A. \& MCLEOD, J.A. - The zoology of tapeworms. London, Minnesota Press, 1952. p. 362-364

9. COSTA, H.M.; CORREA, L. \& BRENER, Z. - Novo caso humano de parasitismo por Bertiella mucronata (Meyner, 1895), Stiles \& Hassall, 1902 (CestodaAnoplocephalidae). Rev. Inst. Med. trop. S. Paulo, 9: 95-97, 1967.

10. CRAM, E.B. - A species of the cestode genus Bertiella in man and the chimpanzee in Cuba. Amer. J. trop. Med., 8: 339-344, 1928.

11. D'ALESSANDRO, A.; BEAVER, P.C. \& MASI PALLARES, R. - Bertiella infection in man in Paraguay. Amer. J. trop. Med. Hyg., 12: 193-198, 1963.

12. DENEGRI, G.M. - Consideraciones sobre sistemática y distribución geográfica del género Bertiella Stiles \& Hassall, 1902 (Cestoda-Anoplocephalidae) en el hombre y en primates no humanos. Neotrópica, 31: 55-63, 1985.

13. DENEGRI, G.M. - Desarrollo experimental de Bertiella mucronata Meyner, 1895 (Cestoda-Anoplocephalidae) de origen humano en su huésped intermediario. Zbl. Vet.-Med., 32: 498-504, 1985.

14. DENEGRI, G.M. - Movilidad in vitro y poder infestante de oncósferas de Bertiella mucronata (Cestoda-Anoplocephalidae) de orígen humano. Rev. ibér. Parasit., 46: 59-61, 1986.
15. DENEGRI, G.M. - Review of oribatid mites as intermediate hosts of tapeworms of the Anoplocephalidae. Exp. appl. Acariol., 17: 567-580, 1993.

16. DENEGRI, G.M. \& PEREZ-SERRANO, J. - Bertiellosis in man: a review of cases. Rev. Inst. Med. trop. S. Paulo, 39: 123-127, 1997.

17. DENEGRI, G.M.; BERNADINA, W.; PEREZ-SERRANO, J. \& RODRIGUEZCAABEIRO, F. - Anoplocephalid cestodes of veterinary and medical significance: a review. Folia parasit., 45: 1-8, 1998.

18. FELDMAN, R.; DENEGRI, G.M.; AVOLIO, J. \& CANTU, N. - Nuevo caso humano de teniasis por Bertiella mucronata Meyner, 1895 (Cestoda-Anoplocephalidae) en la Argentina. I. Diagnóstico y tratamiento. Acta bioquim. clín. latinoamer., 17: 571$578,1983$.

19. GALAN-PUCHADES, M.; FUENTES, M. \& MAS-COMA, S. - Parasitismo importado en Valencia: primer caso de Bertiellosis humana en España. In: CONGRESO IBÉRICO DE PARASITOLOGÍA, 4., Santiago de Compostela, 1995. Resúmenes. p. $197-198$

20. GARAGUSO, P. \& MENDEZ, O. - Primer caso argentino de parasitismo humano por Bertiella mucronata (Meyner, 1895). In: CONGRESO LATINOAMERICANO DE PARASITOLOGÍA, 6., São Paulo, 1983. Resumos. p. 232.

21. PESSOA, S.B. - Sobre um caso de parasitismo humano por cestoide anoplocephalideo do genero Bertiella. Bol. Soc. Med. Cirurg., 14: 158-162, 1930.

22. POPE, B.L. - Some parasites of the howler monkey of northern Argentina. J. Parasit., 52: 166-168, 1966.

23. SANTA CRUZ, A.; GOMEZ, L. \& de ROTT, M. - El parasitismo en Alouatta carayá y Saimiri boliviensis ingresados al "Centro Argentino de Primates". Rev. Med. vet. (B. Aires), 76: 150-152, 1995.

24. SCHIMIDT, G.D. \& ROBERTS, L.S. - Foundations of Parasitology. Saint Louis, C.V. Mosby, 1977.

25. STILES, C.W. \& HASSALL, A. - Bertiella new name for this cestodes genus Bertia Blanchard, 1891. Science, 16: 402, 1902.

26. STUNKARD, H.W. - The morphology and life history of the cestode Bertiella studeri. Amer. J. trop. Med., 20: 305-332, 1940.

27. STUNKARD, H.W.; KOIVASTIK, T. \& HEALY, G.R. - Infection of child in Minnesota by Bertiella studeri (Cestoda-Anoplocephalidae). Amer. J. trop. Med. Hyg., 13: 402-409, 1964

28. WARDLE, R.A. \& MCLEOD, J.A. - The zoology of tapeworms. London, Minnesota Press, 1952. p. 362-364.

29. YAMAGUTI, S. - Systema Helminthum. The cestodes of vertebrates. London, Interscience Publishers, 1959. p. 374-375.

Received: 4 December 2001

Accepted: 16 April 2003 